\title{
Ethical Considerations of Japanese Business Culture
}

\author{
Kat Yamamoto \\ Eastern Oregon University \\ Robert A. Lloyd \\ Fort Hays State University
}

Japanese business ethics, culture, and practice are unique to Japan, and there is limited academic literature in the West (Fukukawa, \& Teramoto, 2009; Iwao,1997; Mizuo, 1998; Oh, \& Koh, 2016; Todeschini, 2012; Tsalikis, \& Seaton, 2008; von Staden, 2016; Wagner-Tsukamoto, 2008; Wang, 2010). The objective of this literature review is to research 1) traditional business ethics concepts and its development in Japan, 2) Japanese corporate citizenship behavior, and 3) Japanese managerial and employee business ethics to help American business leaders better understand Japanese business ethics culture. Current trends relative to business ethics in Japan are being discussed as needed throughout this paper. Finally, this paper draws a conclusion and practitioner implications. How Japanese business people perceive the U.S. business practices and approach are discussed as well.

\section{INTRODUCTION}

The global landscape of business ethics is currently changing as companies increasingly interact with foreign MNE's and expand their own business operations (Vollrath et. al, 2017; Lloyd, 2016). Cultural differences between countries is a well-established field, most notably by Hofstede (1980). However, business research focused on understanding the cultural practices within the business context needs to be developed. This is particularly relevant as globalized markets become more integrated (Lloyd, 2015). Business ethics in Japan is not well studied or published in the West for academics and practitioners to engage in business with the Japanese effectively (Fukukawa, \& Teramoto, 2009; Iwao,1997; Mizuo, 1998; Oh, \& Koh, 2016; Todeschini, 2012; Tsalikis, \& Seaton, 2008; von Staden, 2016; WagnerTsukamoto, 2008; Yamamoto \& Lloyd, 2019; Wang, 2010). What is considered ethical in Japan is not well known to those in the U.S (Allen, 2018; Alston \& Takei, 2005; Azar, 2016; Dunfee \& Nagayasu, 1993; Engel, 2003; Lewis, 2017; Sagers, 2018). One way to investigate how the Japanese handle business ethics issues might be to study how Keidanren (Japan Business Federation), an influential business association in Japan, advances policies and ideas about Japanese business ethics such as corporate citizenship behavior, and corporate social responsibility (CSR).

Due to a lack of ample academic literature on Japanese business ethics in the West, this research uses peer-reviewed journal articles and academic sources available in George Fox University's academic library databases and surveys several relevant Japanese business ethics areas beneficial for the Western business researchers and practitioners to engage in global business with the Japanese, who have unique 
history and business culture. The author of this paper is bicultural (American and Japanese) and bilingual (English and Japanese), and she uses her multicultural experience and understanding to create this literature review.

Thus, the objective of this literature review is to study 1) business ethics concepts and its development in Japan, 2) Japanese corporate citizenship behavior, and 3) Japanese managerial and employee business ethics. Current trends relative to business ethics in Japan is being discussed as needed throughout this paper. Finally, this paper draws conclusions regarding practitioner implications.

\section{Business Ethics Perspectives in Japan}

The concepts of fairness and responsibility relative to business ethics in Japan needs to be understood from the unique perspectives and approaches to ethics in Japan (Allen, 2018; Alston \& Takei, 2005; Azar, 2016; Inamori, 2009; Kotter, 1997; Matsushita, 2015; Iwao, 1994). Ethics is interrelated with spirituality in Japan. Iwao (1994) explains Japanese spiritual normative dimensions relating to ethics: 1) self and 2) collective, and 3) cultural and social dimension in work and business (Japanese business ethics framework).

Spirituality and normative business ethics in Japan is influenced by Confucianism, Buddhism, and Shintoism. These spiritual values in Japan not only influence individuals' cognitive processes and behaviors, but also the collective beliefs and the perception of reality as collective (Allen, 2018; Alston \& Takei, 2005; Azar, 2016; Inamori, 2009; Kotter, 1997; Matsushita, 2015). For example, Japanese spirituality emphasizes that both individuals and collectives have their own spiritual element that is connected to the universe. The cultural and social Japanese business ethics framework allows protocols to be applied within context. The interrelationship of the spiritual and social circumstances leads to multiple views of individuals and collectives.

\section{Normative Spiritual Business Ethics in Japan}

To understand the traditional business ethics culture in Japan, it is necessary to study Japanese cultural background. According to Iwao (1994), Japanese ethical behaviors are categorized into 1) conscious and 2) unconscious values, which can be described as 1) spiritual beliefs (conscious) and 2) social framework (unconscious). Moreover, according to Iwao (1994), Japanese culture cannot be understood without the discussion of the two values simultaneously. The first value is spiritual ideal of human salvation, and the second value refers to the social context which Japanese people interact with another in.

The first spiritual dimension entails norms of behavior to Japanese people's personal development and in relation to the universe. These spiritual norms and values guide one's decisions and actions, thus, it is normative (Iwao, 1994). It is normative because one should follow the expected spiritual norms and live according to sets of values (Johnson, 2017). According to Iwao (1994), there are two normative contexts in Japan: 1) transcendental normative context and 2) collective normative context.

\section{Spiritual Normative Business Ethics in Japan (of Individuals)}

There is a well-known saying in Japan, "though there are many paths to realize enlightenment, they all lead to the direction of the same ultimate goal" (Matsushita, 2015). This proverb teaches us that one can experience multiple phenomena to develop oneself spiritually. In Japan, it is believed that each individual phenomenon has its own spiritual energy and is connected to the universe. This universal energy or life force is called michi (path to righteousness or enlightenment), ri (justice), and ho (Buddhist order) (Alston \& Takei, 2005; Dunfee \& Nagayasu, 1993; Lewis, 2017; Mente, 1994; Sagers, 2018; Inamori, 2009; Matsushita, 2015). This transcendental spirituality in Japan is a philosophy that every experience and phenomenon is an expression of the universal and sacred energy.

In this transcendental spiritual context, each individual has spiritual element or life force within. This concept has been supported by Confucianism, Buddhism, and Shintoism. Because individuals are believed to have a microcosm of life force within themselves and are an expression of the universal energy or macrocosm, their inner life force can connect with the external universe. 
In Buddhism, every living being is believed to have Buddha nature (Inamori, 1995). This idea is similar to the idea of having universal life force within. Buddhism teaching that though there are differences among living sentient beings, human beings equally have the Buddha nature. The Buddha nature cannot be destroyed of taken away by anything. Any human being has the opportunity to become enlightened Buddha through spiritual practice and purification of the mind (Dunfee \& Nagayasu, 1993).

People in Japan traditionally worship within both Buddhism and Shinto contexts simultaneously. It is common to find both a Buddhist alter and a Shinto shrine in Japanese homes. Additionally, in this transcendental spiritual and normative context, not only individuals but also objects, nature, places, rituals, and organizations are associated with the universal life force. For example, deities of Shintoism and Buddhism are called the great force of life (Lewis, 2017).

Many Japanese people do not visit Buddhist temples and Shinto Shrines on a regular basis the way Americans visit Churches each week to worship. Japanese believe that by being mindful of their thoughts and actions, each movement, behavior, and activity can be used to transform their mind to attain enlightenment and spiritual development. Some Japanese may not belong to specific religious sects, but they accept the way of thinking as part of Japanese spiritual culture. Whether believing in religion or not, Japanese people accept its transcendental normative ethics culture that is shared in Japanese business environment.

\section{Meaning of Work for Japanese People}

Japan traditionally has work-centric business culture, and often described as workaholic (Lane, 2017; Nishiyama \& Fujikawa, 2017). This is because people in Japan live in a spiritual and normative environment that encourages personal development to support the collective goals and wellbeing. To them, working for the collective happiness and growth is the identity and the meaning of their existence (Sagers, 2018). As such, meaning of work for the Japanese becomes uniquely spiritual as well. The work becomes self-expression of the universal life force. The act to engage in work itself has its own life energy connected to the universe, so for them, work becomes a way to attain the ultimate spiritual awareness or enlightenment (Lewis, 2017).

The quest of Japanese to reach the spiritual mindfulness and development can be found in many ritualistic activities such as tea ceremony, flower arrangement, martial arts, and calligraphy (Sagers, 2018). Tireless practice and mastering a skill are thought of as becoming closer to kami (a godlike state). No matter what kind of work Japanese people do, when they pour their mind and effort completely and focus their efforts into the task, they are respected by their peers and the group, and they are on their way to reach the state of kami (Inamori, 1997).

While Western leaders place value on innovation, leaders in Japan place priority on kaizen (continuous improvement of process, products, operations, decision making, and strategy) (Brunet \& New, 2003; Dramalieva, 2010; Jayne, 2010; Jeffrey, 2014; Liker, \& Hoseus, 2008; Liker, 2004; Liker \& Franz, 2011; Liker \& Ross, 2016; Macpherson, Lockhart, Kavan, \& Iaquinto, 2015). Though innovation can be accomplished by a small number of elites in the West, Japanese believe that kaizen can be endlessly carried out by nearly anyone (Ohno, 2012; Ohno \& Bodek, 1988). The transcendental normative spiritual environment in Japan contributed to the development of their tendency to put emphasis on kaizen (to continue to improve each moment. Thus, work is an essential way for Japanese people to reach spiritual enlightenment and to become one with the universal life force. For this reason, Japanese tend to be perfectionistic, prefer to conform to gyouji (rituals) and kata (traditional forms) because they believe that doing so shows respect to elders and ancestors who worked hard to provide better life for the current generation.

Because Japanese see work as holy and honorable, they are loyal to their employers, peers, and the group. Japanese dislike taking it easy at work, and they are passionate about improving their products and services, operations, and work processes. Japanese believe serving the customer and satisfying them with high quality products and service is the ultimate goal and socially responsible business act to take. These traditional Japanese philosophies toward work are influenced by the transcendental normative work settings. 
Japanese business ethics culture expects Japanese people to work hard due to its normative spiritual work environment, and Japanese value dedication to work and diligence as virtue. Under Japan's collectivistic spiritual work culture, they encourage people to work hard to reach their spiritual development as well as serving the team, group, and others (Inamori, 2004). This culture has not yet created extremely individualistic workers who focus only their short-term interests (Matsushita, 2015). This is because when Japanese people hope for job security, they understand that to serve others is not just a selfless act but also improves the situation of self by bettering the long-term collective wellbeing (Liker, \& Hoseus, 2008; Liker, 2004; Liker \& Franz, 2011).

\section{Spiritual Normative Business Ethics in Japan (of Group and Collective)}

The second spiritual normative business ethics to give not only to individuals who work, but also to give the transcendental normative ethics to their work groups or teams. In the transcendental environment, each group or team has its own universal life force. Thus, helping each other in the group and encouraging each other to reach their potential leads to spiritual development of both the members and the group (Taka, 1994).

Traditionally, typical units of group in Japan is ie (family), mura (local community), and kuni (nation). Once a group is formed, a group works toward its survival and growth in the spiritual and normative business environment. Within the group, sets of norms such as protocols are followed to maintain order, and are also called the logic of the group.

The group-oriented characteristic of Japan comes from the group normative work environment. Often Japanese people apologize profusely to show humility and care to the others and the group when individuals and groups are experiencing difficulties, or when they make a mistake. Apologizing in Japan does not automatically mean admitting guilt or responsibility the way the U.S. culture does. However, apologizing in Japan is used to maintain the harmony, show respect to the members of the group, family, and others, especially because each group and each individual has its own universal life force that should be honored (Iwao, 1994).

\section{Ethical Dilemma between the Two Spiritual Normative Business Ethics in Japan}

Sometimes Japanese people experience ethical conflicts because they exist in two separate spiritual normative work environments of the self and the group. Though the spiritual element of the self and the group are both respected and valuable, the group is considered priority to the self in Japan. This is because the universal life force of the group is more powerful than that of the self. Also, it is considered that the way for individuals to connect to the universal life force is through the power of the group they belong to (Shinomiya \& Szepkouski, 2007; Taka, 1994).

Depending on the context of normative spiritual business ethics settings of self and group, in Japan, group takes priority above the self. As long as harmony within the group can be maintained, individuals can pursue their own interests. However, once individuals demand more than the group can allow to keep the peace in the group, the group will require individuals to be more selfless so that ethical conflicts will not result between the individuals and the group, and this way of thinking is the group logic. Rarely, an individual may leave the group but such situation is not ideal (Iwao, 1994; Shinomiya \& Szepkouski, 2007; Taka, 1994; Inamori, 1995, 1997, 2004, 2009; Matsushita, 2015).

The leaders in the group will ask the followers to follow the protocol and in this case is tatemae (formal order). Tatemae exists for the group to have a unified decision on external environment. To adjust to the external environment to survive as a group, the group requires the members to put individual differences aside and conform to the group. On the other hand, honne (real feelings/motives) is the opposite of tatemae. To have smooth group decisions and activities, honne is generally suppressed and tatemae is followed in a group (Iwao, 1994; Shinomiya \& Szepkouski, 2007; Taka, 1994; Inamori, 1995, 1997, 2004, 2009; Matsushita, 2015).

Confrontations in Japanese business culture is avoided as much as possible to save face and uncomfortable communication. Thus, conflict between tatemae and honne needs to be avoided. Whether leaders or followers have individual conflict between their honne and tatemae, the group leaders 
encourage everyone to be on the same page, and to make consensus decisions to avoid disruption of harmony (Iwao, 1994; Shinomiya \& Szepkouski, 2007; Taka, 1994; Inamori, 1995, 1997, 2004, 2009; Matsushita, 2015).

\section{Individuals, and the Family Unit (Self)}

Humans are social beings; thus, they live in their social circles of family, peers and coworkers, and larger society (nation and globe). The family circle is created of parents and children, and sometimes close relatives such as grandparents, grandchildren, uncles, and aunts. At a quick glance, the family circle of Japanese people may look male-dominant and females perform support roles to men who are the primary earner of the family. In Japanese culture, mothers are very devoted to their children and are often the homemakers for the family unit (Davies, 2016; Davies \& Ikeno, 2002; Mente, 1994; Mente, 2015). Mothers encourage harmony and peace in the family. The head of the family unit are the fathers, and they generally make the final decisions of any important issues such as education or career path of their children (Davies, 2016; Davies \& Ikeno, 2002; Mente, 1994; Mente, 2015). Any decisions that involve long-term impact of a family member are decided by the fathers who are the family leaders.

In the family unit, the members are expected to practice humbleness and gratitude for what they receive. Spiritually and ethically, it is virtuous to show appreciation for parents, grandparents, and ancestors for their kindness to provide for the family so that the members can survive, thrive, and prosper (Davies, 2016; Davies \& Ikeno, 2002; Mente, 1994; Mente, 2015). It is expected that children will repay the kindness of family members who took care of them, and give back to their children, and care for parents and grandparents when they become adults (Davies, 2016; Davies \& Ikeno, 2002; Mente, 1994; Mente, 2015).

\section{Coworkers, and Wider Social Circles (Group and Collective)}

The next social unit to the family in Japan consists of peers and colleagues, friends and distant relatives. This social unit usually consists of managers, supervisors, and peers from work. In this social circle, spiritual and professional reciprocal interactions are balanced in the long run (Davies, 2016; Davies \& Ikeno, 2002; Mente, 1994; Mente, 2015). It is expected that one pays back the kindness and support received from the members of this social circle. A polite and reserved attitude is expected in this circle to save face of each other because creating uncomfortable confrontations should be avoided. Failing to act properly according to protocols can result in shame, which is frowned upon (Davies, 2016; Davies \& Ikeno, 2002; Mente, 1994; Mente, 2015).

The next level of social unit in Japan encompasses wider society, and it includes the nation. In this circle, Japanese people become strangers in their spiritual and social environment. People do not openly criticize each other here. They do not have close relationships so it is not expected to behave as reserved to strangers, but it is still expected to act polite and respectful. It is expected that people act with longterm reciprocal attitude in this social circle (Davies, 2016; Davies \& Ikeno, 2002; Mente, 1994; Mente, 2015).

The last social unit is global society, which comes after the family, the close social circle, and larger social circle as the bases of spiritual ethics culture in Japan. This unit includes overseas countries and cultures. The attitude of Japanese people may differ towards the international society. Some may be closed off due to acting risk-averse to the differences in global society, and some may be intrigued by new ways of thinking and attitudes of other countries. In general Japanese are open to outside cultures and are eager to learn as well as give back and respect other countries (Davies, 2016; Davies \& Ikeno, 2002; Mente, 1994; Mente, 2015).

\section{Japanese Corporations}

Japanese business ethics culture has a family-like atmosphere. Comparable to social circles of individuals, families, and their social environment with their expected group interactions within, corporations in Japan also have a similar inclination to describe their work environment. The first level is the close family-like unit in the workplace. Though employees at Japanese corporations are not related by 
blood, they commonly have close partnerships. For instance, parent or affiliated companies are considered as a family-like unit. Vertically integrated keiretsu industrial companies have parent and child relationship, which are intimate. Horizontally integrated keiretsu groups are thought of as having familylike relationships to each other as well, though they are not as close as vertical keiretsu (Davies, 2016; Davies \& Ikeno, 2002; Mente, 1994; Mente, 2015). Research shows a clear relationship between these levels of social connections and the impact on workplace motivation (Lloyd \& Mertens, 2018).

Next, each Japanese corporation has its own main Japanese bank, traders, affiliated companies, and established customers (Tsalikis, \& Seaton, 2007; Wagner-Tsukamoto, 2009). When the Japanese corporation's board members or executives belong to business associations such as Nihon Jidousha Kogyo Kai (Japanese Automobile Manufacturers Association), Keidairen (Japan Business Federation), Doyukai (Japan Association of Corporate Executives) and so on, other members from business associations may comprise of the close circle of that corporation (Davies, 2016; Davies \& Ikeno, 2002; Mente, 1994; Mente, 2015; Tsalikis, \& Seaton, 2007; Wagner-Tsukamoto, 2009).

The reciprocal relationship of taking care of each other needs to be balanced within the circle. It is expected that the corporations need to offer opportunities and receive opportunities with one another to keep the harmony (Iwao, 1994). The consideration for the mutual benefit stems from Confucianism. Confucianism lets people treat each other based on the closeness of the relationship. Unlike Christianity, Confucianism does not teach people to care for one another equally (Johnson, 2017). Confucianism encourages those who are close to look after each other, and this is done to avoid conflict of interest. The logic is that when people try to treat every member equally in a social setting, often there will be differences in interests. It does not mean that Confucianism tells people to not care for strangers. The important idea is that though people should treat every individual as a human being deserving of appropriate treatment, people should care for those who are close to them because those who cannot be kind to close family members cannot care for strangers. This differential reciprocation principle applies to Japanese corporations (Davies, 2016; Davies \& Ikeno, 2002; Mente, 1994; Mente, 2015).

In Japanese business society, the free competition principle applies to companies that are unrelated. However, corporations know that long-term reciprocal ethics is important in developing and maintaining business relationships because they operate in the Japanese business culture (Davies, 2016; Davies \& Ikeno, 2002; Mente, 1994; Mente, 2015).

In the global business world, Japanese corporations follow the principle of free competition as well, but they are less concerned about the need to follow the customs within Japanese business society. The goal of Japanese corporations in the global competition is to deliver high quality and low-price products and to dominate as much market share as possible abiding to laws and regulations (Davies, 2016; Davies \& Ikeno, 2002; Mente, 1994; Mente, 2015).

Japanese multinational corporations operating overseas work with diverse human resources. Japanese companies expect employees who are not ethnically Japanese to understand the existing Japanese business ethics practices so that they can maintain the normative approaches unique to Japan. On the other hand, because Japan has been influenced by the U.S. since the end of WWII, Japanese people admire Western technologies and innovations of the U.S. as well as European nations (Davies, 2016; Davies \& Ikeno, 2002; Mente, 1994; Mente, 2015).

\section{Work-Centric Attitude}

Japanese are driven to work long and hard from their spiritual and cultural pressures. Karoshi, death due to overwork, is a serious problem in Japan (Kanai, 2009). Karoshi is the result of working long hours that resulted in the worker's deterioration in health; both mental and physical. Some Japanese people commit suicide due to fatigue and depression from constantly working overtime. Others die on the job from heart attack or other health conditions due to stress of work long hours (Kanai, 2009). More Japanese companies are now managing costs by limiting the number of full-time employees with benefits while using more part-time employees without benefits; though the Ministry of Health Labor and Welfare in Japan encourages a full-time employee to be working no more than 1,800 hours a year. More 
responsibility is given to full-time salaried employees, and it is still common for them to work 60 or more hours a week (Kanai, 2009).

\section{Perception of the Japanese Businesses by the West}

Since Japanese businesses and people follow their traditional transcendental logic and group normative ethics, their way of doing business may seem unique to the Westerners. Japanese business culture and ethics are distinct from other nations, so it may bring misunderstanding to international business partners such as the U.S., European, Asian, and other developed and developing countries. As such, this paper attempts to explain how Japanese people observe the U.S. businesses through a Japanese normative business ethics lens.

In the Japanese transcendental normative setting, whatever work people are given, they are expected to reach the similar level of human resource development. Because of this human resource approach, Japanese are less likely to evaluate others in terms of specialty of work within a Japanese corporation (e.g. human resource, technical, sales, production, etc.). Japanese employees tend to relate to one another in terms of their united attitude toward work for a corporation (Davies, 2016; Davies \& Ikeno, 2002; Mente, 1994; Mente, 2015).

It is not particularly important for Japanese to maintain the principle of the division in work. To them, the process is more important than the short-term result. When they cannot attain the goals in an existing framework of division of labor, they would seek an alternative approach as a group. On the other hand, individualistic society like in the U.S., where job descriptions are clearly specialized, Japanese perceive such division as lacking harmony and inflexible. Workforce in the U.S. may believe that the division of labor allows for efficient use of diverse talents. However, Japanese believe that people should help one another and perform each other's work because they are working for the same company and group (Davies, 2016; Maruta, 1992; Mente, 2015; Shinomiya \& Szepkouski, 2007; Taka, 1994).

\section{Individual Interest and Collective Work Logic}

Shibusawa explains that ideology plays a significant role in shaping ethical business practice in Japan (Shibusawa, \& Latz, 2014). Identifying the transgression of business ethics in developed Western nations is different from that is developing economies where social and institutional framework and the lapse in ethical behavior is in the process of change or development. When historic practices of business were a closed from outside world and Japanese government interaction continue into the new age, ethical restraint might be more learning experience than transgression (von Staden, 2016).

In the group normative setting in Japan, the group is believed to hold its own universal life force. A corporation is thought to exist for its employees, shareholders, as well as stakeholders. Though in the past, it was thought that ethically, the U.S. corporations should serve primarily the interests of shareholders and not the stakeholders. However, since the financial crisis of $2000 \mathrm{~s}$, globally, corporations are believed to serve both the shareholders and the stakeholders (Bowie, 2008; Chandler \& Werther, 2013; Johnson, 2017). Thus, the approaches to corporate social responsibility and organizational citizenship behaviors of Japanese and the U.S. corporations are now converging (Davies, 2016; Maruta, 1992; Mente, 2015; Shinomiya \& Szepkouski, 2007; Taka, 1994).

\section{CONCLUSION}

This paper examined the basic ethical issues of the Japanese business culture from the spiritual and social dimensions. The spiritual normative ethics is composed of both transcendental and group logics unique to Japan. The social dimensions involve the individual, family, wider society in Japan, and the society beyond the Japanese boarder.

Because Japanese business ethics culture is rooted in traditional spirituality, group, and social logics, it is challenging, if not impossible to suggest changes or improvements for Japanese business practice within Japan (Davies, 2016; Mente, 2015; Shinomiya \& Szepkouski, 2007; Taka, 1994). Historically, cultural relativism is a difficult topic to resolve in cross-cultural business ethics research (Robertson, 
1993). Additionally, historic and comparative data of business ethics is challenging to collect (Oh, \& Koh, 2016).

Though Japanese corporations such as Toyota and Sony were favorably received by the global market for their quality products, Japanese businesses have had their share of scandals with Livedoor and others committing similar unethical acts of Enron in the U.S. (Mizuo, 1998; Tsalikis, \& Seaton, 2007). Japan as well as China are rooted in Confucian ethics philosophy influencing all aspect of people's lives including how the businesses are practiced. Kyosei (symbiosis) philosophy has a significant influence on organizational behavior in Japan (Tsalikis, \& Seaton, 2007).

According to Todeschini (2012), Japanese ideals, ba (place) and kokoro (heart), which shape the concepts of social and collective responsibility, suggest significant difference from Western concepts of CSR. Wang (2011) explains that management commitment to CSR mission might enhance individual employee performance and organizational citizenship behavior in Japan. Because most of the academic literature on CSR focuses on the West and studies the public aspects of CSR, more research of social responsibility in Japanese business context is needed to draw conclusive recommendations for how the Western businesses can better engage in global business negotiations and CSR initiatives with the Japanese corporations (Fukukawa, \& Teramoto, 2008; Todeschini, 2012).

However, Japanese corporations operate internationally, and are using global human resource strategies to work with a diverse workforce in many nations (Kraimer, Wayne, \& Jaworski, 2001; Major, Kozlowski, Chao, \& Gardner, 1995; Maruyama, 1992; Mizuo, 1998). Japanese people have a curious nature toward outside nations and cultures (Shinomiya \& Szepkouski, 2007; Taka, 1994). Japanese business leaders are humble enough to learn from others who know more than themselves, and adapt to varying national cultures, ethics, and customs overseas.

\section{REFERENCES}

Allen, G. C. (2018). Japan the hungry guest. Palala Press.

Alston, J., \& Takei, I. (2005). Japanese business culture and practices: A guide to twenty-first century Japanese business. New York, NY: iUniverse, Inc.

Azar, R. C. (2016). Navigating Japan's business culture: A practical guide to succeeding in the Japanese market. Write Way Publishing Company LLC.

Bowie, N. E. (2008). Stakeholder theory: Essential readings in ethical leadership and management. Amherst, N.Y: Prometheus Books.

Brunet, A. P., \& New, S. (2003). Kaizen in Japan: an empirical study. International Journal of Operations \& Production Management, 23(11), 1426-1446.

Chandler, D., \& Werther, W. B. (2013). Strategic corporate social responsibility: Stakeholders, globalization, and sustainable value creation. (3rd edition). Thousand Oaks, CA: Sage Publications.

Dalai Lama. (2006). The universe in a single atom: The convergence of science and spirituality. New York, NY: Harmony.

Dalai Lama. (2009). The art of happiness: A handbook for living. New York, NY: Riverhead Books.

Davies, R. J. (2016). Japanese culture: The religious and philosophical foundations. Tokyo, Japan: Tuttle Publishing.

Davies, R. J., \& Ikeno, O. (2002). The Japanese mind: Understanding contemporary Japanese culture. Boston, MA: Tuttle Publishing.

Dunfee, T. W., \& Nagayasu, Y. (1993). Business ethics: Japan and the global economy. Boston, MA: Springer.

Engel, D. W. (2003). Passport Japan: Your pocket guide to Japanese business, customs \& etiquette. Novato, CA: World Trade Press.

Fukukawa, K. \& Teramoto, Y. (2008). Understanding Japanese CSR: The reflections of managers in the field of global operations. Journal of Business Ethics, 85, 133-146. 
Hofstede, G. (1980). Culture's consequences: International differences in work-related values. Thousand Oaks, CA: Sage

Inamori, K. (2009). A compass to fulfillment: Passion and spirituality in life and business. (1st ed.). New York, NY: McGraw-Hill.

Inamori, K. (1995). A passion for success: Practical, inspirational, and spiritual insight from Japan's leading entrepreneur. New York, NY: McGraw-Hill.

Inamori, K. (1997). For people and for profit: A business philosophy for the 21st century. Tokyo, Japan: Kodansha USA Inc.

Inamori, K. (2004). Life: The most important thing as a human. Tokyo, Japan: Publishing Sanmaku.

Iwao, T. (1994). Business ethics: A Japanese view. Business Ethics Quarterly, 4(1). 53-78.

Jayne, V. (2010). Masaaki Imai KAIZEN GURU. New Zealand Management, 57(3), 40.

Jeffrey, J. (2014). Kaizen: Doing it the Japanese way. African Business, 408, 156-158.

Johnson, C. E. (2017). Meeting the ethical challenges of leadership: Casting light or shadow (6th ed.).

Los Angeles, CA: Sage Publications.

Kanai, A. (2008). Karoshi (work to death) in Japan. Journal of Business Ethics, 84, 209-216.

Keidanren. (2018). About Keidanren. Retrieved from http://www.keidanren.or.jp/en/profile/pro001.html.

Kotter, J. P. (1997). Matsushita leadership. ( $1^{\text {st }}$ ed.). New York, NY: Free Press.

Kraimer, M. L., Wayne, S. J., \& Jaworski, R. A. A. (2001). Sources of support and expatriate performance: The mediating role of expatriate adjustment. Personnel Psychology, 54(1), 71-99.

Lane, E. (2017). The young Japanese working themselves to death. BBC News. Retrieved from https://www.bbc.com/news/business-39981997

Lewis, D. C. (2017). Religion in Japanese daily life. New York, NY: Routledge.

Liker, J., \& Hoseus, M. (2008). Toyota culture: The heart and soul of the Toyota way. New York, NY: McGraw-Hill.

Liker, J. K. (2004). The Toyota way: 14 management principles from the world's greatest manufacturer. New York, NY: McGraw-Hill.

Liker, J. K., \& Franz, J. K. (2011). The Toyota way to continuous improvement: Linking strategy and operational excellence to achieve superior performance. New York, NY: McGraw-Hill.

Liker, J. K., \& Ross, K. (2016). The Toyota way to service excellence: Lean transformation in service organizations. New York, NY: McGraw-Hill.

Lloyd, R. A., \& Mertens, D. (2018). Expecting more out of Expectancy Theory: History urges inclusion of the social context. International Management Review, 14(1), 28-43.

Lloyd, R. A. (2015). A brief history of globalized markets: Implications for managers. Journal for Global Business Education, 14, 5-11.

Lloyd, R. A. (2016). CHS Country Operations' international business strategy. Journal of the North American Management Society, 10(1), 66-84.

Macpherson, W. G., Lockhart, J. C., Kavan, H., \& Iaquinto, A. L. (2015). Kaizen: A Japanese philosophy and system for business excellence. Journal of Business Strategy, 36(5), 3-9.

Major, D. A., Kozlowski, S. W. J., Chao, G. T., \& Gardner, P. D. (1995). A longitudinal investigation of newcomer expectations, early socialization outcomes, and the moderating effects of role development factors. Journal of Applied Psychology, 80(3), 418-431.

Maruyama, M. (1992). Changing dimensions in international business. The Academy of Management Executive, 6(3), 88.

Matsushita, K. (2015). The Path. (1st ed.). New York, NY: McGraw-Hill.

Mente, B. D. (1994). Japanese etiquette \& ethics in business. Lincolnwood, IL: McGraw-Hill.

Mente, B. L. D. (2015). Etiquette guide to Japan: Know the rules that make the difference! Tokyo, Japan: Tuttle Publishing.

Mizuo, J. (1998). Business ethics and corporate governance in Japanese corporations. Business and Society Review, 102, 65-79. 
NBC News. (n.d.). First step in changing Japan's workaholic culture: Less overtime. Retrieved from https://www.nbcnews.com/news/world/first-step-changing-japan-s-workaholic-culture-lessovertime-n833051

Nishiyama, G., \& Fujikawa, M. (2017). Japan, which invented workaholics, tells employees: Go home already! Wall Street Journal. Retrieved from https://www.wsj.com/articles/japan-which-inventedworkaholics-tells-employees-go-home-already-1509634033

Oh, I., \& Koh, Y. (2016). The state as a regulator of business ethics in Edo Japan: The Tokugawa authority structure and private interests. Asia Pacific Business Review, 22(3), 397-410.

Ohno, T. (2012). Taiichi Ohno's workplace management. New York, NY: McGraw-Hill.

Ohno, T., \& Bodek, N. (1988). Toyota Production System (TPS): Beyond large-scale production. Cambridge, MA: Productivity Press.

Robertson, D. C. (1993). Empiricism in business ethics: Suggested research directions. Journal of Business Ethics, 12(8), 585-599.

Sagers, J. H. (2018). Confucian capitalism: Shibusawa Eiichi, business ethics, and economic development in Meiji Japan. Palgrave Macmillan.

Shibusawa, M. \& Latz, G. (2014). Rediscovering Shibusawa Eiichi. Tokyo, Japan: Shibusawa Eiichi Memorial Foundation.

Shinomiya, S., \& Szepkouski, B. (2007). Business passport to Japan. Berkeley, CA: Stone Bridge Press.

Tsalikis, J. \& Seaton, B. (2007). The international business ethics index: Japan. Journal of Business Ethics, 80, 379-385.

Todeschini, M. M. (2012). Webs of engagement: Managerial responsibility in a Japanese company. Journal of Business Ethics, 101, 45-59.

Vollrath, M., Lloyd, R. A., \& Liu, Y. (2017). A new standard for global education: A case study of Duke Kunshan University. In Alphin, H. C., Lavine, J., \& Chan, R. Y. (Eds.), Exploring the Future of Accessibility in Higher Education, IGI Global, 21-36.

von Staden, P. (2016). A socio-cognitive approach to business ethics: Lessons from early industrializing Japan. Asia Pacific Business Review, 22(3), 411-421.

Wang, Y. (2011). Mission-driven organizations in Japan: Management philosophy and individual outcomes. Journal of Business Ethics, 101, 111-126.

Wagner-Tsukamoto, S. (2009). Consumer ethics in Japan: An economic reconstruction of moral agency of Japanese firms. Journal of Business Ethics, 84, 29-44.

Yamamoto, K., \& Lloyd, R. A. (2019). Issues in international labor: A study of Japanese expatriates in Japan-based MNEs in the United States. In George, B., \& Roberts, J. (Eds.), The Changing Landscape of Global Business: Principles and Practices, Cambridge Scholars Publishing. 